\title{
Defining customer experiential knowledge and its dimensions: a conceptualization starting from a netnographic study of specialty coffee blogs
}

\author{
Beatrice letto, Federica Pascucci and Gian Luca Gregori
}

\begin{abstract}
Purpose - This paper aims to develop a theoretical framework for the conceptualization of customer experiential knowledge (CEK) by logically combining its different dimensions into one coherent explanatory concept. Drawing on the integration of the literature on customer experience, customer knowledge management and customer insights acquisition, supported by adequate empirical evidence, the framework provides a systematic, comprehensive and accurate understanding of CEK which, could contribute to the identification of relevant customer experience insights useful for customer knowledge management.

Design/methodology/approach - The analysis follows an inductive/deductive interpretative approach and it is based on a netnography of specialty coffee bloggers' narratives in relation to their sustainability practices.

Findings - The paper identifies the following six types of CEK: normative, subcultural, epicurean, transcendental, subcultural and symbolic. Accordingly, CEK is defined as the knowledge tacitly possessed by customers in relation to how they live their consumption experiences according to a body of heterogeneous socio-cultural contextual factors (ethos, norms and symbols) and subjective influences (emotions, ingenuity, instincts and senses) deeply embedded into the narrative of a consumption experience.

Originality/value - While CEK has been largely observed and acknowledged, it has not been yet adequately addressed by existing research. The provision of a conceptual definition of CEK which emphasizes its different dimensions will be of use to both academics and practitioners to better identify and categorize the different manifestations of CEK when undertaking empirical observations or managerial decisions.
\end{abstract}

Keywords Netnography, Coffee industry, Sustainability, Blogs, Customer experiential knowledge, Customer knowledge acquisition

Paper type Conceptual paper

\section{Introduction}

Today, customer knowledge is recognized as the most important enhancer of a firm's competitive performance and customers the most significant source of knowledge (Fiano et al., 2020; Taghizadeh et al., 2018). However, while most firms like to define themselves as customer-driven, the majority still struggles to effectively implement a customer focus (Zhang, 2011).

A customer focus can be achieved through the acquisition of a comprehensive multidimensional understanding of customers, including product usage, preferences and needs, as well as information about the actual consumption experiences (CX) (Zhang,
Beatrice letto is based at Universita Politecnica delle Marche, Ancona, Italy. Federica Pascuccib and Gian Luca Gregori are both based at the Department of Management, Faculty of Economics Giorgio Fua, Università Politecnica delle Marche, Ancona, Italy.

Received 23 December 2020 Revised 18 February 2021 31 March 2021

Accepted 4 May 2021

() Beatrice ietto, Federica Pascucci and Gian Luca Gregori. Published by Emerald Publishing Limited. This article is published under the Creative Commons Attribution (CC BY 4.0) licence. Anyone may reproduce, distribute, translate and create derivative works of this article (for both commercial and non-commercial purposes), subject to full attribution to the original publication and authors. The full terms of this licence may be seen at http:// creativecommons.org/licences/ by/4.0/legalcode 
2011). First introduced by Holbrook and Hirschman (1982), over the years, the concept of customer experience evolved from a cognitive and rational process toward a more holistic practice involving rational, as well as hedonic aspects of consumption (Becker and Jaakkola, 2020), associated with sensations, implicit meanings and emotions (Carù and Cova, 2007).

As our society is moving into an experience economy and consumers increasingly longing for hedonic gratification through consumption (Hirschman and Holbrook, 1982), consumption experiences have become one of the most compelling antecedents of firms' competitive advantage (Pine and Gilmore, 1998; Verhoef et al., 2009). While a holistic and expanded understanding of customer experiences could assist firms to improve their offering, gaining customer knowledge in relation to their experiences remains a challenging task (Holmlund et al., 2020). In fact, knowledge related to customer experiences cannot be considered factual or data-driven and, being deeply rooted inside individuals, it can only be accessed or managed through a systemic and elaborate effort (Chua and Banerjee, 2013). According to Jaziri, customer experiential knowledge (CEK) can be considered as tacit knowledge which cannot be consciously accessed and it includes all the different meanings that consumers give to their consumption practices. Besides Jaziri's incidental description of CEK, within knowledge management studies, a deeper understanding of customer experiences has been rarely integrated into traditional models of customer knowledge management (CKM) (Jaziri, 2019). For example, the very same Gebert et al. (2003) influential model "knowledge for, from and about" is rarely to be found or implemented in relation to the analysis of customer experiences (Bratianu et al., 2020). In fact, being the research on CEK still in the beginning, the knowledge management field has called for more conceptual works that provide an expanded, comprehensive and systematic understanding of CEK, as well as frameworks, which might facilitate its extraction and formalization (Bratianu et al., 2020; Holmlund et al., 2020; del Vecchio et al., 2020; Chierici et al., 2019).

Based on these premises, it can be argued that, although CEK has been largely observed and acknowledged, it has not been adequately explained by the existing research. Therefore, to address this gap, the purpose of the paper is to develop a conceptual framework, which is based on empirical evidence and integrates literature on customer experience, CKM and customer insights acquisition. The framework contributes to a systematic and structured identification of customer insights relevant to CX management, as, on the contrary to previous frameworks used for differentiating among types of customer knowledge, it emphasizes the more tacit and in-depth components of CX. Considering that today the experience component is dominating almost all the consumption experiences, such an expanded and more in-depth understanding could assist firms to improve their value proposition and marketing strategies.

In particular, we formulate the two following research questions:

$R Q 1$. What are the different types of CEK?

$R Q 2$. Drawing on these types, how can CEK be conceptualized?

By addressing the above questions, the paper contributes to knowledge management studies through the provision of an empirically based conceptualization of CEK which will be of use to both academics and practitioners for systematic identification and analysis of the different manifestations of CEK. Considering that consumption experiences have become a key antecedent of a firm's competitive advantage, the presented framework becomes essential for knowledge management studies.

One important concern with acquiring data coming from customer experiences and translate them into actionable knowledge is that is deeply embedded within individuals and rarely openly stated, their formalization remains problematic (Carù and Cova, 2007). Traditionally, customer knowledge has been acquired through conventional research 
methods such as focus groups, interviews and experiments (Gentile et al., 2007). However, these approaches have been criticized to suffer from respondent inhibition (Elliott and Jankel-Elliot, 2003; Izogo and Jayawardhena, 2018). More recently, developments in big data analysis have unlocked possibilities to gain customer insights for customer experience management. However, they cannot grasp the more in-depth, subjective and hedonic aspects of experiences which indeed lie on the basis of experiential knowledge (Thompson, 2019; Reid and Duffy, 2018). By contrast, qualitative approaches such as netnography, by addressing critical knowledge about more nuanced and emphatic understanding of consumption experiences, are considered as undisputed and powerful methods for a deeper understanding of customer experiences (del Vecchio et al., 2020; Cayla and Arnould, 2014).

Being knowledgeable about customer experience tacit in nature and, therefore, difficult to formalize and share (Polanyi, 1966), for CEK to become explicit, requires to go through externalization processes through social interaction (Nonaka, 1994). Carù and Cova (2008) argue that web 2.0 platforms represent indeed the optimal setting in which consumers externalize their experiences through storytelling. Bloggers, in particular, seem to perfectly embody this capacity of converting lived experiences into explicit knowledge as their narratives are unsolicited and often talk about life events including consumption (Carù and Cova, 2008).

Accordingly, the analysis focuses on specialty coffee bloggers and it adopts a netnographic approach. As coffee consumption has recently evolved from utilitarian to multi-sensory and hedonic, it represents a rather interesting experiential type of consumption (Pascucci, 2018).

Following the above discussion, the paper is structured as follows: the first part presents the theoretical background of the study, detailing its conceptual fundamentals in relation to customer experience, CKM and consumer insights acquisition. The second part describes the research design and methodology. The third part, following an integrative inductive/ deductive interpretative approach (Gioia et al., 2013), outlines the emerging themes which will be further analyzed in the discussion section for a conceptualization of CEK including its different manifestations.

\section{Theoretical background of the study}

Literature pointing toward the conceptualization of CEK is fragmented across the domains of customer experience, CKM and customer insights acquisitions.

\subsection{Customer experience and its different dimensions}

The concept of customer experience was introduced by Holbrook and Hirschman (1982), who first advanced that, being consumers rational problem-solvers and feelers, they experience consumption in very subjective and personal ways, not fully controllable by the firm. Research on CX embraces two different perspectives: organizational and consumer (Kranzbühler et al., 2018). While the organizational perspective deals with a firm's strategies to create and manage CX (Homburg et al., 2017; Schmitt, 2003; Gentile et al., 2007), the consumer's one focuses on the subjective and internal responses that customers have of any direct or indirect contact with a company (Helkkula et al., 2012), especially in relation to hidden emotions, implicit meanings, cognitive and sensorial elements (Verhoef et al., 2009).

This paper follows the consumer's perspective as it seeks to understand how customers, in their unique context, live subjective experiences (Addis and Holbrook, 2001). Being able to understand what consumers experience rather than what they say might allow firms to learn things that not even the customers themselves might be aware of (Thusy and Morris, 2004). 
Customer experience has also been defined as a multidimensional concept by many researchers and its different dimensions have been identified in a number of studies which have been summarized in Table 1. For example, Schmitt (1999) talks about five strategic experiential modules - sense, feel, think, act and relate - which may represent different customer experience dimensions. On the basis of Schmitt's work, Gentile et al. (2007) identified six dimensions: sensorial which stimulates the senses, emotional which stimulates the affective system, cognitive which is connected with thinking or conscious mental processes, pragmatic which comes from the practical act of doing something, a lifestyle which comes from the affirmation of the system of values and the beliefs of a person and relational which regard the relationships with other people. Roederer (2012) found four dimensions: praxeological, hedonic-sensory, rhetorical and time-related. The praxeological dimension relates to the actions taken during consumption experiences seen as ways of doing things, which are ritualized at times; therefore, this dimension could be associated with Gentile et al.'s pragmatic one and to Schmitt's act module. The hedonic-sensory dimension refers to the polarity of pleasure-displeasure associated with an experience, which is described through a sensorial reading of the experiential context; therefore, this dimension can be associated with the Gentile et al.'s sensorial one and Schmitt's sense module. The rhetorical dimension concerns the symbolic meaning of experience while the time-related in Roeder's vision contributes to enriching the praxeological and rhetorical ones.

To the best of our knowledge, the analysis of CX within a knowledge management context has only been discussed by Jaziri (2019) in relation to the innovation of customer service experiences through the management of experiential knowledge. Jaziri defines CEK as a form of tacit knowledge which remains deeply embedded inside individuals' minds but not consciously accessed and includes all the different meanings that consumers give to their consumption practices. According to Jaziri (2019), CEK unintentionally manifests through social interaction embedded within individuals' reflexive practices. Jaziri considers the physical, praxeological and rhetoric dimensions as integrated "under a dynamic interaction between the consumer, the object and the situation" (p. 254). However, she does not explain how the identified experiential dimensions clearly translate into customer tacit knowledge. Jaziri's work mostly emphasizes the importance of construct customer experiential knowledge management as an organizational competence to generate knowledge to obtain successful experience innovation. Therefore, although ground-breaking, Jaziri's definition of CEK is a coincidental by-product of theoretical analysis on the importance of tacit knowledge about customer service experiences as a key external input for innovation.

\subsection{From customer knowledge to different types of customer tacit knowledge}

Customer knowledge is a rather complex and ponderous concept incorporating a broad variety of insights ranging from knowledge possessed by customers as direct product users (Wilhelm et al., 2013) such as reasons for buying and value received (He et al., 2017) but also who they are, what are their preferences and attitudes and how they respond to communication efforts (Rowley, 2002). While there has been a number of approaches in classifying customer knowledge, the most influential is the one represented by Gebert et al. (2003) which differentiates among three main types of customer knowledge: knowledge

Table 1 Different dimensions of customer experience according to the literature

Schmitt (1999)

Schmitt et al. (2015)

Gentile et al. (2007)

Roederer (2012)
Sense, feel, think, act and relate

Sensory, affective, intellectual, bodily and social

Sensorial, emotional, cognitive, pragmatic, lifestyle and relational Praxeological, hedonic-sensory, rhetorical and time related

PAGE 152 JOURNAL OF KNOWLEDGE MANAGEMENT $\mid$ VOL. 25 NO. 112021 
about customers, knowledge from customers and knowledge for customers. Accordingly, different types of customer knowledge insights can be gained through different types of data. Holmlund et al. (2020) argue that consumers' data could be solicited or unsolicited and structured or unstructured. Unsolicited-unstructured data represent the greatest potential for gaining $\mathrm{CX}$ insights as they might lead to identifying more hidden and tacit knowledge about customers' experiences (Holmlund et al., 2020). However, as their research focuses on CX insights meant as knowledge about customers attained through big data analytics, their framework provides only a partial understanding of customer experiences, as because of the intrinsic nature of big data insights, it does not take into account the knowledge possessed by customers in terms of product usage (Gebert et al., 2003), as well as the previously discussed more deep and emphatic side of customer experience.

Customer knowledge can also be explicit or tacit. Explicit knowledge, often referred to as technical knowledge, is mostly studied in relation to innovation and co-creation processes and it can be defined as solutions to problems that consumers face when using products (Busacca et al., 2008; Roberts et al., 2016). Explicit knowledge has the advantages of being relatively easier to identify, capture and transmit. By contrast, tacit knowledge is a fuzzy concept, which can be defined as ideas, skills and experiences that people possess but cannot be codified or easily expressed as people are often not aware of the knowledge they possess and its potential value to others (Polanyi, 1966).

While the majority of studies have focused on the distinction between tacit and explicit knowledge (Jaziri, 2019), there are also several classifications of tacit knowledge types which, although often using different labels, essentially convey the same meaning (Table 2). For example, the concept of affective knowledge as defined by Bennet and Bennet (2008) is similar to the emotional knowledge of Bratianu (2015) or Dinur's (2011) and it describes individuals' reactions to external events and agents or unexpressed - perhaps, not even recognized - feelings. Practical tacit knowledge, defined by Rix and Lièvre (2008) as embodied knowing which manifests during a particular situation, can be associated with Bennet and Bennet's (2008) and Collins' (2010) intuitive knowledge, meant as the sense of knowledge coming from the inside, as well as Castillo's (2002) sagacious knowledge. Embodied tacit knowledge (Bennet and Bennet, 2008; Blackler, 1996) and somatic tacit knowledge (Collins, 2010) concern the human senses such as taste or smell, through which information enters the body, as well as movements of the body such as riding a bicycle (Polanyi, 1966). Finally, socio-cultural tacit knowledge (Castillo, 2002), collective tacit knowledge (Castillo, 2002) and encultured knowledge (Blackler, 1996) all relate to knowledge learned, used and shared by socio-cultural systems, deeply embedded into specific cultural contexts (Castillo, 2002) and learned through socialization (Blackler, 1996).

\subsection{Customer knowledge acquisition in online platforms}

Although tacit knowledge can be shared by individuals during socialization, its capture still remains an unsolved issue for many firms. Extant literature mostly pertains to the domain of

\section{Table 2 Different types of tacit knowledge in the literature}

Bennet and Bennet (2008)

Castillo (2002)

Bratianu (2015)

Collins (2010)

Rix and Lièvre (2008)

Blackler (1996)

Dinur (2011)
Embodied (kinesthetic and sensory), affective, intuitive and spiritual Non-epistle, semantic, sagacious and socio-cultural Emotional, spiritual and cognitive Relational, somatic, collective and intuitive Practical Embodied, encultured, embrained, embedded and encoded Skill, cause-effect, cognitive, cultural, unlearning, taboo, human and emotional 
innovation and new product development (NPD) and it investigates the mechanisms or strategies for transferring customer's tacit knowledge into NPD processes such as observing customers during product or concept testing (Bretschneider and Zogaj, 2016).

The raise of web 2.0 has partially helped to overcome this problem and, in fact, today usergenerated content is considered one of the most important spaces to capture customer insights (He et al., 2017) and web tools are likely to be among the latest enablers of tacit knowledge-sharing (Del Giudice et al., 2015). Web 2.0 has disrupted the entire knowledge management process as it has enabled consumers to create, exchange and share an unprecedented amount of information about their consumption and product usage which, when adequately managed, becomes an irreplaceable knowledge asset (Chua and Banerjee, 2013; Levy, 2009). In comparison to more traditional research methods such as surveys or in-depth interviews, user-generated content is a more authentic and trustworthy representation of consumers' voices because of its natural occurrence (Levy, 2009). According to Wagner et al. (2014), social media may be seen as a "cyber ba," because they enable and support knowledge activation at a certain time and in a shared space by enabling and facilitating human interactions and collaboration.

Consumer-driven platforms (Hofacker and Malthouse, 2016) such as online communities and blogs, are considered suitable sources for tacit knowledge acquisition as they are not firm driven nor purposely focused to obtain explicit or technical knowledge (for example, "My Starbucks Idea" in Chua and Banerjee, 2013). They provide unobtrusive unsolicited data, usually more personal and deeper, resulting from spontaneous interaction among highly involved consumers (Kozinets, 2020). Furthermore, being tacit knowledge more easily shared by individuals during socialization (Nonaka, 1994), they can be considered as one of the most important spaces to capture customer insights (He et al., 2017).

Despite the multitude of approaches available to firms for customer knowledge acquisition, big data approaches have recently received particular attention. Text mining technologies adopted by these approaches potentially offer an efficient and effective way to extract and manage customer knowledge (del Vecchio et al., 2020; Usai et al., 2018; Roberts et al., 2016), however, research combining big data analysis with CKM remains, overall, scarce (Holmlund et al, 2020; del Vecchio et al., 2020). In fact, an increasing body of literature has been highlighting the need for interpretative frameworks useful to integrate social media data with knowledge management perspectives (Holmlund et al., 2020; del Vecchio et al., 2020; Chierici et al., 2019).

Although the big potential of social media data, firms still experience several issues in gaining relevant and usable knowledge from big data (He et al., 2017; Said et al., 2015; del Vecchio et al., 2020) or might use analytics of doubtful reliability for their decision-making (Ransbotham et al., 2015). Furthermore, as big data approaches tend to gather data through machine-driven mechanical algorithms, they cannot grasp the more deep, subjective and hedonic aspects which indeed lie at the basis of experiential knowledge (Thompson, 2019; Reid and Duffy, 2018).

By contrast, qualitative approaches such as netnography, represent consolidated approaches for a deeper and insightful comprehension of customer experiences through interpretive cultural analysis of introspective narratives usually diffused by consumers in the forms of text, audio, video or images through social media (Kozinets, 2020; del Vecchio et al., 2020).

To conclude, despite a rich body of literature about customer experience, CKM and customer insights acquisition, the above analysis reveals a lack of a clear definition of CEK and a thorough investigation of its conceptual breath. In particular, excluding few studies on customer insights acquisition, the above research streams have been mostly been studied as separate fields. Specifically, Holmlund et al. (2020) develop a framework for customer experience management based on $\mathrm{CX}$ insights coming from big data analysis. Although the 
article differentiates among different types of customer insights and different experiential dimensions, they do not differentiate between tacit and explicit knowledge, as well as among the different types of tacit knowledge. Furthermore, they consider exclusively big data approaches for insights acquisition. Similarly, del Vecchio et al. (2020) propose an integrative approach of big data analysis and netnography to gain different types of customer knowledge for customer relationship management. However, they do not explicitly address CEK and its multidimensionality, how it relates to tacit knowledge and how it can be only be acquired from specific types of insights.

Based on such premises, the paper positions the CEK concept at the crossover of the above-discussed bodies of literature (Figure 1).

\section{Research design and methodology}

As the research aims at uncovering tacit elements of knowledge and its experiential embeddedness, netnography is the most appropriate approach to understand the aspects of "knowing more than we can tell" (Kane et al., 2006). Netnographic approaches have been widely used for investigating customer experience in different contexts such as tourism and winery (Rageh et al., 2013; Massa and Bédé, 2018).

Originally mastered by Kozinets as a form of online ethnography, netnography has been recently modernized to take into account the emergence of social media and assembling together a mix of qualitative methods inquiries required for the variety of data available today. Through participants' observations in their own natural context, netnography studies the cultures and communities that emerge from online communication using interpretative techniques of cultural anthropology (Geertz, 1973). The collected data might consist of online observations, visualizations, data scraping, archival work, interviews, etc.

Following the recommendations of Chaney et al. (2018), this paper adopts a "zoom-in" approach, in the sense that it focuses on a specific experiential context - the coffee

\section{Figure 1 Literature pointing at CEK and research gap}

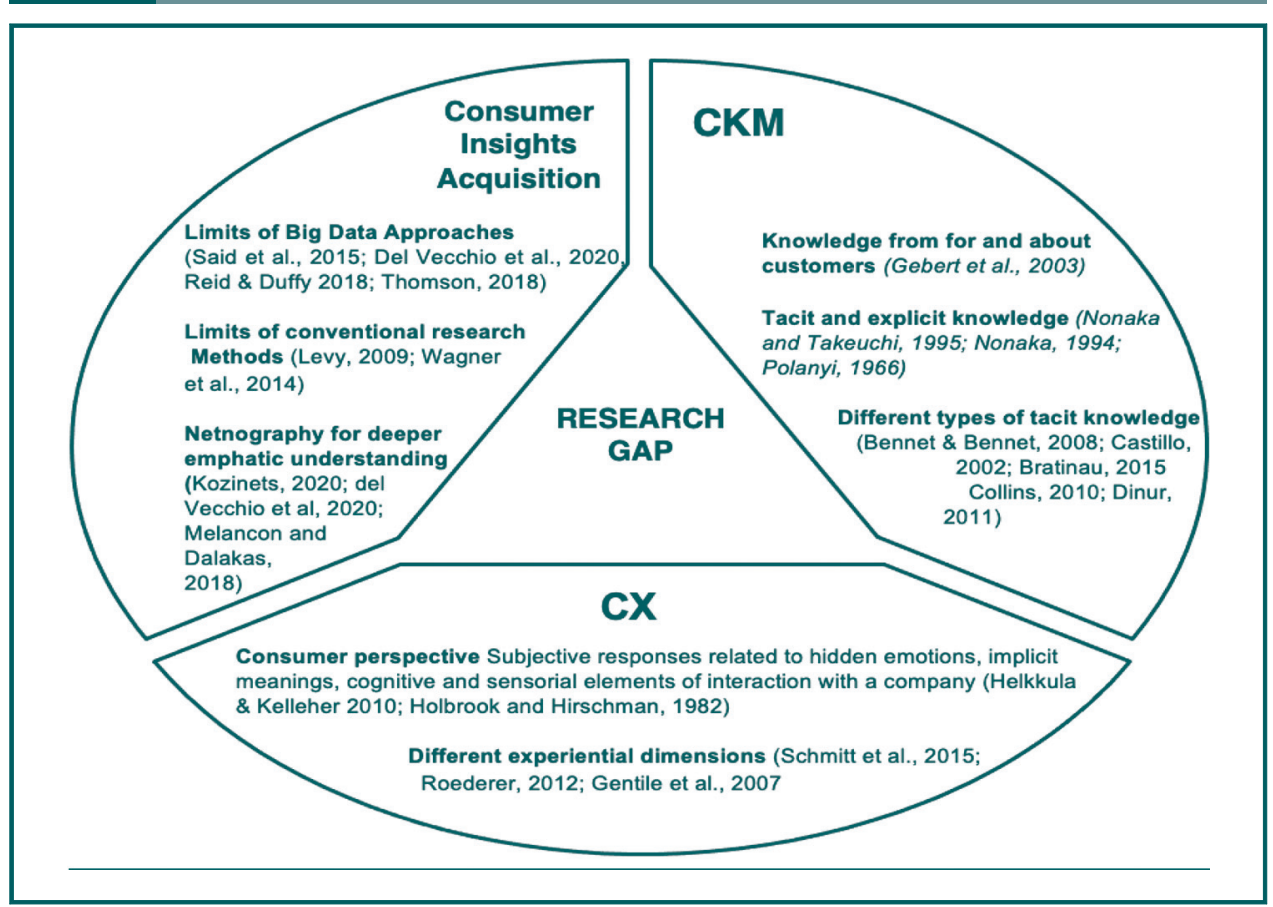

VOL. 25 NO. 112021 JOURNAL OF KNOWLEDGE MANAGEMENT $\mid$ PAGE 155 
business - to favor a micro-analytical level and take into consideration the idiosyncratic nature of the consumption experience. Among the wide variety of blogs, which exist today, special interest bloggers are particularly relevant as they often treat specific niches of hedonic consumption interests (Hsu and Tsou, 2011). Therefore, we based our analysis on specialty coffee blogs. Coffee is a suitable context as coffee consumption, from being just utilitarian, has recently become a multi-sensory experience (Eiseman and Jonsson, 2019), a global luxury fashionable item, drunk in boutique cafes and prepared with almost technocratic attention to production and consumption (Pascucci, 2018). In combination with the emergence of specialty coffee, consumers have also started demanding greater sustainability practices throughout the entire value chain of coffee production and consumption (Guimarães et al., 2019). The growing consumers' concern over sustainable issues in their purchase decisions is impelling businesses to provide offerings, which are more sustainable (Jang et al., 2015).

Data were collected starting from two bloggers posts mentioning the most influential coffee blogs in 2019 (Kozinets, 2020) complemented with the inclusion of the blogrolls of the initial 40 blogs and, being bloggers' particularly active on Twitter (Quintao, 2017), their Twitter followers which were also specialty coffee bloggers. The number totaled 74 . Following a purposive sampling approach (Belk et al, 1988), promotional business blogs, inactive blogs and blogs not specifically addressing sustainability were discarded leading to a total of 43 blogs. To specifically select posts discussing topics related to sustainability, each blog was manually searched via an Advanced Google Search [1]. Bloggers' posts were eventually complemented by Twitter data (Quintao et al., 2017) of each of the initial 74 bloggers accounts, collected as data sets through NCapture (Table 3).

As in Hollebeek et al. (2017), the analysis followed an integrative inductive/deductive interpretative approach. Data were coded through the software NVivo following an inductive approach from empirical to conceptual (Gioia et al., 2013), which abstracts concepts from the subjective interpretation of the data and it looks for emerging themes within the implicit meaning of the narratives to then use them to generate theory from the bottom up (Kozinets, 2020; p. 315). The aim of this approach is to understand how bloggers discuss and create meaning of sustainability in relation to coffee consumption. To preserve bloggers' expressions, data were first coded using an open coding approach (Gioia et al., 2013) and during the second-order analysis, axial coding (Strauss and Corbin, 1998) was used to identify similarities and differences among the first-order codes. This process merged topics related to each other into new higher-order more abstract themes (Gioia et al., 2013), following a thematic analysis (Terry et al., 2017; Kozinets, 2020).

The emerging themes were then deductively analyzed within the context of the extant literature (Taylor and Bogdan, 1984) and reorganized into more abstract aggregate dimensions relevant to identify how their narratives incorporate types of tacit knowledge,

\section{Table 3 Summary of data sources}

\begin{tabular}{|c|c|c|}
\hline Source & Data collection approach & Type of data \\
\hline 43 coffee blogs & $\begin{array}{l}\text { Pre-established keywords* } \\
\text { were searched via Google } \\
\text { Advanced Search on } 74 \\
\text { coffee blogs }\end{array}$ & 222 blog posts including comments \\
\hline $\begin{array}{l}74 \text { Twitter accounts of } \\
\text { coffee bloggers }\end{array}$ & $\begin{array}{l}\text { Accounts were mined using } \\
\text { Nvivo extension's Ncapture } \\
\text { and, once onto Nvivo, a text } \\
\text { search* was performed }\end{array}$ & 856 tweets \\
\hline $\begin{array}{l}\text { Non-coffee blogs and } \\
\text { coffee online magazine }\end{array}$ & Tweet's links & 12 posts/articles including comments \\
\hline
\end{tabular}


which could be associated with experiential dimensions (Gioia et al., 2013). For example, the aggregate dimension "action-oriented practices and sustainable behaviors," which discusses how the introduction of more sustainable behaviors would create a disruption to the functional elements of bloggers consumption practices, incorporates 2 nd order themes such as "barriers preventing the adoption of reusable practices" (Svenson, 2018), "solutions for pods reusability," "solutions for recycling pods and bags," "behavioral adjustments for the adoption of reusable practices," "reusability as a normative social convention" (Table 4). The 2nd order theme "barriers preventing the adoption of reusable practices" incorporates first-order concepts emphasizing functional difficulties experienced by bloggers in the adoption of reusable cups (bulky, leaking, hard to clean, etc.), while the theme "solutions to overcome problems encountered with pods and bags" includes first-order concepts discussing how bloggers were coming up with their own solutions and ideas to adopt a more sustainable consumption.

\section{Findings}

The aggregate dimensions identified from the further abstraction of the second-order themes represent the key findings. Their analysis was conducted deductively using the previously identified types of $C X$ and tacit knowledge as theoretical categories leading to the identification of the types of CEK emerging from bloggers' narratives (Gioia et al., 2013). Table 5 shows the entire coding process from which aggregate dimensions were deduced.

\section{Table 4 Sample of the coding process}

First-order concepts - open coding (Gioia et al., 2013)

Leave a sticky note to not forget it

Hot coffee lovers should be quicker as some cups cool down quick

For "green" use of pods machine, reusable pods and grounded coffee

Reusable pods need to be cleaned and filled but more sustainable

Carrying around a reusable cup at all times is a pain for occasional users

Occupy a large space and bulky

Hard to clean

Most standard reusable cups will leak

Portions control, dirty cups, size fitting issues for baristas

For refillable K-cup leaks, a rubber band around the top of the bottom section will seal it

Came up with a way to reuse the K-cup far more than 10 times

I created a filter out of unbleached cotton that replaces the paper filter

Reusing the small cups for growing seedling plants in the spring

Cool ways to repurpose coffee grounds

Pods can be recycled by the consumer ripping and

disassembling the components

Recyclable pods need to be taken at collection points

Valve and plastic film disassembling is required before disposal

The change away from disposable cups will happen only when done collectively.

It will no longer be cool for fashion or coffee bloggers to have

photos of disposable coffee cups

Reusable is desirable

It can be inconvenient at times, but it is a matter of habit/routine
Second-order themes - axial coding (Gioia et al., 2013; Kozinets, 2020)

Behavioral adjustments for the adoption of reusable practices

Barriers preventing the adoption of reusable practices

Solutions for pods reusability

Solutions for recycling pods and bags

Reusability is a normative social convention
Aggregate dimensions (Gioia et al., 2013)

Actions-oriented practices and sustainable behaviors 
Behavioral adjustments for the adoption of reusable practices

Barriers preventing the adoption of reusable practices

Solutions for pods reusability

Solutions for recycling pods and bags

Reusability is a normative social convention

Good and sustainable coffee is for here

For-here coffee in disposable cups perceived as a social and negatively emotionally

loaded practice

More complex coffee brewing, although require more human effort, minimize waste

There are times where what's right for flavor and what's right for the environment go

hand-in-hand

Take-away cups evaluation based on sensorial pleasure

For-here cups evaluated through tasting ritual involving all the senses

Sensorial displeasure used to judge lack of coffee appreciation

Sensorial pleasure and taste are more important than sustainability when buying coffee

Eco-friendly disposable practices are a false illusion

Fairtrade labels are misleading

The value of sustainability has lost authenticity

Demonstrating the fakeness of compostability claims

Negative attitude toward low commitment guilt relief sustainability

Too much sustainability is perceived as not authentic and creates displeasure

Pods perceived as unsustainable and low-quality

If pods are consumed more sustainably, they lose the convenience

Refusal of the value of convenience

Mainstream brands perceived as unsustainable and devaluing coffee experience

FT coffee tastes good and is sustainable

Convenience is more important than taste and sustainability

Even little actions do count for the environment

Corporate brands sell good coffee

Keeping sustainability as an elitist value harms the environment

Coffee appreciation implies sustainability consciousness

Gradual development of sustainability and coffee appreciation one step at the time

Mindfulness and awareness needed for sustainability and coffee appreciation
Actions-oriented practices and sustainable behaviors

Ritualized consumption and sustainability

Sensorial skills and pleasure for the evaluation of consumption experiences

Sustainability as a co-opted and abused value

Contrasting attitudes toward mainstream consumption practices

Coffee appreciation and sustainability as journeys toward self-actualization

\subsection{Actions-oriented practices and sustainable behaviors}

This first theme analyzes bloggers habits meant as routinized practices for coffee consumption which involve predetermined and established sets of utilitarian and functional actions, "ways of doing things" (Schau et al., 2009), motivated by rational decisions such as satisfying practical needs or providing solutions to problems (Hirschman and Holbrook, 1982). Take-away consumption, for example, is considered a convenient, well-established and popular routine for time-poor bloggers. Cook and Brown (1999) argue that established routines are a body of tacit knowledge acquired by individuals through over-time repetition. Roederer (2012) considers these actions an experiential praxeological dimension meant as intentional behaviors adopted during a consumption experience determined by the context of consumption.

For example, bloggers switching from disposable to reusable cups to behave more sustainably, need to modify their current behavior by introducing new habits such as "cleaning the cup after use," "carrying the cup around all day" and "remembering the cup in the morning." Bloggers willing to modify their habits would then readjust their routine introducing new actions such as "leaving a sticky note to remember the cup" (Svenson, 2018). The introduction of a new action - e.g. sticky note - represents the understanding of the appropriate doing and it can be considered as a tacit aspect of knowing, what is to be done in certain situations or "knowing in practice" (Gherardi, 2016, p. 686). Bennet and 
Bennet (2008) call it intuitive tacit knowledge meant as a sense of knowing from the inside, knowledge of what is right to do but not knowing why. Bloggers, in fact, identify issues to overcome only as they manifest during the action such as the facts that cups "occupy large space," "are hard to clean," "leak" and "can be forgotten." Rix and Lièvre (2008) call it "knowing-in-action" as part of what they define as practical tacit knowledge. In relation to home consumption, more ingenious bloggers displaying further commitment to overcoming sustainability problems were providing unique ideas for recycling such as manual disassemble of pods into components or reuse for other activities such as gardening. Statements such as "I created a filter out of unbleached cotton that replaces the paper filter" or "I came up with a way to reuse the K Cup far more than 10 times" reflect the creative skills that bloggers acquired through direct experience: a technical dimension of tacit knowledge grounded in action (Nonaka and Takeuchi, 1995). These solutions could be considered either a form of sagacious tacit knowledge (Castillo, 2002) or intuitive knowledge (Bennet and Bennet, 2008) as they show an acute and intuitive practical sense, being bloggers able to clearly identify the problem and come up with creative solutions to it. However, when a new habit is not yet deeply embedded into an individual established routine, a conflict between intention and action might raise. For example, not all bloggers were prepared to disrupt their established routines:

We're sure a lot of coffee aficionados share our troubled conscience every time we order to-go, but let's face it, who has the time to dine in these days? If only travel mugs were better (GetaCoffeeMaker).

Besides the reluctance of some bloggers in overcoming their behavioral barriers, overall, bloggers seem appreciative of more sustainable practices: "Today I am pledging to break my own habit of using paper cups and advocating that you also bring your own reusable togo cup to your local shop" (OneShot).

For example, as the acceptance of reusable cups increases, such behavior might eventually become the appropriate doing and possibly be considered as a collectively accepted and shared convention (Scaraboto and Fischer, 2013). Consequently, consumers would invest more effort into its adoption (McCracken, 1990): "Great job making reusable, desirable. With a mug like this, I'd gladly deal with the 'inconvenience' of carrying it and washing it, just to be seen with it" (Brian's Coffee Spot).

The affirmation of reusable cups into the system of values and behaviors of a consumption experience can be considered what Gentile et al. (2007) call the lifestyle experiential dimension as their adoption will become means of adhesion to certain values. Reusable cups represent the implicit meaning of what is right to do, therefore, they can also be considered as a form of collective tacit knowledge as they embody the social convention of taking away coffee consumption (Collins, 2010). Collins argues that collective tacit knowledge enables individuals to perform actions that require an understanding of the social context to be properly performed (2007). This knowledge is usually located within the society and cannot be codified.

\subsection{Ritualized consumption and sustainability}

The second theme analyzes consumption routines corresponding to actions motivated by hedonic and symbolic decisions (Roederer, 2012). For example, while take-away consumption is a habit, for-here coffee (meant as consumption sitting at a café served in a porcelain cup) is considered as a ritual, defined as an intentional expressive behavior adopted as a way to differentiate from mass consumers (Rook, 1985) through which bloggers can enjoy more hedonic and symbolic aspects of consumption instead of utilitarian (Roederer, 2012). For-here consumption follows predefined appreciation rituals which only bloggers with greater cultural competence and knowledge would perform as it 
involves a series of implicit rules for tasting, preparing and evaluating coffee (Kozinets, 2002; Maciel and Wallendorf, 2017):

The best espresso cups are chosen to provide the right amount of thermal insulation while providing a shape that best suspends the delicate crema that sits on top of the espresso (The Coffee Compass).

Rituals can be considered as a form of collective or socio-cultural tacit knowledge as they enable bloggers to perform actions that require an understanding of the cultural context to be properly performed (Collins, 2010; Castillo, 2002). As the ritual performance often implies greater understanding and capacity for coffee appreciation, for-here coffee becomes a means to construct an identity as a coffee expert (Holt, 1995; Rook, 1985) as the symbolic significance of the practice integrates with the self through a semiotic transfer. Therefore, for-here coffee represents semantic or encoded tacit knowledge, defined by Castillo (2002) and Blackler (1996) as the symbolic significance given to words, acts or other phenomena. Such meaning is tacit in nature and does not need to be explained or explicitly mentioned as it is incorporated within actions (Castillo, 2002).

While for-here consumption is intrinsically embedded with sustainability, by contrast, forhere consumption in disposable cups provoked strong disappointment among bloggers causing the arousal of negative emotions (Schmitt et al., 2015): "wandered past one of many @Starbucks branches in Shanghai. Every customer who was drinking in (it was large and full) had a disposable cup. Shameful" (Brian's Coffee Spot). The discrimination toward those lacking sensorial skills and sustainability sensitiveness also embodies semantic tacit knowledge (Castillo, 2002) as bloggers use its rejection as a form of distinction (Bourdieu, 1984) and status denial (Holt, 1995; Arsel and Bean, 2013).

\subsection{Sensorial skills and pleasure for the evaluation of consumption experiences}

The theme analyzes how bloggers use senses to evaluate experiences and make decisions. According to Maciel and Wallendorf (2017), hedonic types of consumption are reflexive experiences, usually evaluated following structured and complex procedures involving all the senses (Roederer, 2012; Gentile et al., Schmitt et al., 2015). The sensorial information processed during consumption is evaluated according to some learned associations which trigger an emotional response either corresponding to pleasure or displeasure (Polanyi, 1966). Bloggers methodically use all their senses for evaluating the pleasure associated with different types of cups. Cups are assessed through structural elements based on sensorial hints including better taste, tactile and visual impressions (Hirschman and Holbrook, 1982): "sipping holes should have a size large enough to take in the aroma" and the rounded design of some lids "make drinking more enjoyable."

The aesthetics of the cups, involving the visual dimension, were also extremely important for achieving maximum pleasure as "coffee tastes better when served in a nice cup" (Coffee Stylish). The capacity of coffee appreciation, as seen in the discrimination among types of cups, is displayed through judgments which are often subtle, spontaneous and going beyond mere explanations: "Would you drink a single malt scotch out of a paper cup?" (The Shot).

Judgments like this, are based on somatic tacit knowledge (Castillo, 2002) expressed as the capacity of an individual to discern, through a sensorial evaluation, qualities and relationships that other individuals are less likely to see.

According to Polanyi (1966), the sense-impression and the immediate recognition are part of the same moment and the judgment occurs without having the conscious awareness of the rules guiding the judgment. In this context, bloggers possess knowledge and experience sharpened through continuous sensorial exercise resulting in developing a sense of taste, which is subtle and intuitive. Bennet and Bennet call it embodied tacit 
knowledge learned through behavioral training (2008) and expressed through the capacity of appreciation which is used by bloggers as a source of distinction from mainstream consumers (semantic knowledge):

While the environmental debate may still be out, why overlook the fact that espresso tastes far better in a real cup? Would you dine out at a fine restaurant and request that everything is served in a plastic basket, wrapped in aluminum foil? (The Shot).

Therefore, as the above quotes show, bloggers would adopt a critical stand against consumption practices lowering sensorial pleasure.

\subsection{Contrasting attitudes toward mainstream consumption practices}

This theme analyzes the divide among bloggers with opposing beliefs in relation to the mainstream market and their impact on the lifestyle dimension (Gentile et al., 2007) of their consumption experience. On one side, there were bloggers showing an overall positive attitude toward mainstream brands as they believed that offering such as pods systems provided a positive tasting experience:

"New pods improved enormously in quality of sourcing and sophisticated brewing devices bringing back the aroma and flavor of brewed coffee"; as well as convenient: "Bottom line for me is, the Keurig in my office is fast, clean, makes a hot cup of coffee and it's just a cup of coffee [... ] not a glass of fine wine" (Reader's comment).

For example, among these bloggers, Fair Trade coffee emerges as a strongly eradicated and collectively shared value as they showed a strong commitment to it (Geertz, 1973, p. 187). In fact, Fair Trade can be considered as a social convention whose understanding and appreciation will vary based on the cultural and relational context as what is expected as sustainable behavior will vary considerably based on the social context (Gentile et al., 2007)

Blackler (1996) calls it encultured knowledge referring to shared understandings achieved through socialization and acculturation. Collins (2010) calls it collective tacit knowledge meant as "the knowledge that the individual can acquire only by being embedded in society" and it is located within society as humans are highly influenced by what others think and do. For example, while for some bloggers Fair Trade coffee "not only ensures fair living wages for coffee farmers, they take into account environmental standards," for others "FT creates an unsustainable and artificial economic system where farmers are given no incentives to grow better coffee."

Ultimately, beliefs will depend on the relational dimension of the consumption experience (Gentile et al., 2007) meant as a group-specific situation (Blackler, 1996). On the opposite side, other bloggers were entirely against mainstream brands as perceived as abusing sustainability for commercial purpose: "What was once an alternate is now becoming coopted and industrialized in the name of product marketing by the big coffee producers it originally intended to counteract" (The Shot).

Such denial of a value consequent to its co-optation is typical of "subcultures of consumption" (Kozinets, 2002), defined as a group of people sharing a common ethos defined in opposition to the broader mainstream cultural context of reference (Thornton, 1996): "'Buy green' gives consumers the false illusion of environmentally friendly products and that the more they buy the more they save the environment" (I need coffee).

In this case, eco-friendly practices are only perpetuating consumption logics and sustainability is seen as an abused value to encourage more consumption. Corporate brands, in particular, were accused of promoting disposable consumption which sits in dialectical opposition to the ethos of specialty coffee (semantic tacit knowledge) "making coffee ritual like a water stop in marathon race" (Bean Thinking). 
A core premise of such opposing values and beliefs among bloggers is that individuals, although belonging to the same socio-cultural system, sharing a common passion, are simultaneously embedded in multiple cultural contexts each with their own values, beliefs, norms and guiding principle. This can potentially lead to contradictions and tensions among bloggers which, although sharing the passion for specialty coffee, are embedded in different cultural systems (Scaraboto and Fischer, 2013). Such opposing values (Thornton, 1996) can be considered socio-cultural tacit knowledge as they embody those norms about appropriate behaviors and the system of values and beliefs of a person within a given group context (Castillo, 2002). The refusal of consumption practices such as pod systems, associated with mainstream consumption is instrumental to a denial of status (Holt, 1995; Arsel and Bean, 2013) and, therefore, they can be considered as a form of semantic or encoded tacit knowledge (Castillo, 2002; Blackler, 1996).

\subsection{Sustainability as a co-opted and abused value}

This theme analyzes the value that bloggers give to sustainability and their attitude toward sustainable practices. Overall, sustainability was a deeply embedded value among bloggers which, although with different degrees of involvement, showed an overall appreciation and commitment for more sustainable consumption practices. Interestingly though, when sustainable practices would demean the consumption experience, sensorial pleasure would prevail over sustainability as in the case of Fair Trade coffee: "buying coffee should not be an act of charity" and decisions should be based on what satisfies the consumer the most: "I'd rather have good coffee than fair coffee" (Serious Eats). For bloggers:

There is GOOD quality Fair Trade coffee and that there is BAD quality Fair Trade coffee and that

it doesn't help anyone just buy blindly without considering flavor and preference (Serious Eats).

Therefore, consistent with Quintao's finding (2017), although sustainability was overall highly valued, it remained subordinate in comparison to taste and sensorial pleasure as embedded with an implicit symbolic meaning signifying status as coffee experts (semantic/ encoded knowledge). Criticism seemed also to emerge toward brands parading too much sustainability as they were perceived as abusing the value: "Some cafes seem too busy saving the world than to make a great-tasting espresso" (Bean Poet).

For bloggers, "trying too hard" (Thornton, 1996) on sustainability was in fact perceived as status denial (semantic knowledge) and reducing the sensorial pleasure of the consumption experience (embodied tacit knowledge):

The list of causes and do-goodness is so in-your-face, it's honestly a bit too much here. I applaud them for their well-intended causes, but I like to have a good espresso without feeling like I'm marinating in them (The Shot).

Similarly, they were also perceiving low-commitment sustainability practices as a cheap and weak effort for conscience's relief: "The desire for a simple solution to existing is so strong that consumers we are willing to commit to the first thing that comes by and sounds promising."

The implicit meanings given to sustainability in the above examples (socio-cultural tacit knowledge) were ascribed only by a distinctive sub-group of bloggers sharing a common set of beliefs in opposition to the larger cultural system of mainstream consumption (sociocultural knowledge) (Hebdige, 1979).

\subsection{Coffee appreciation meant as mindfulness, awareness and consciousness}

This theme analyzes coffee consumption as a self-actualization experience deeply embedded with moral and ethical meaning. We have previously discussed how for-here coffee maximizes sensorial pleasure and arouses a number of positive emotions including also tranquility and peace of minds (Schmitt, 1999; Schmitt et al., 2015): "specialty coffee is 
a treat to be pleasured spending some time in a café" and "an invitation to be more careful, thoughtful, conscious and not to hurry." Such mindfulness and thoughtfulness stand in explicit opposition to consumers favoring convenience which instead "drink their coffee like runners at a marathon refreshment station," missing the most important part of consuming coffee. For-here coffee is seen as an invitation to thoughtful consumption which allows individuals to be more sensitive and aware of their own emotions and, therefore, have more intense emotional experiences (Schmitt et al., 2015) imbued with positive feelings of peacefulness, tranquillity and mindfulness (affective tacit knowledge) (Bennet and Bennet, 2008; Bratianu, 2015). Interestingly, for bloggers, mindfulness in coffee appreciation often implies more environmental consciousness which is gradually developed the more one becomes involved with coffee appreciation (Bennet and Bennet, 2008): "Is there a parallel between trying to live more sustainably and the art or science, of coffee appreciation?" (Bean Thinking).

For bloggers to achieve the maximum authentic experience in terms of coffee appreciation and sustainability they need to undertake a gradual acculturation journey (Blackler, 1996) focusing on morality and respect of universal values (Bratianu, 2015):

I am far too aware that I'm on a sustainability journey: There is still so much more to learn, so many new things to experience, it is a journey I'm very happy to have embarked upon. Some do a lot better with environmentalism, some are still drinking instant coffee, but small steps help us to make the large steps that are going to be needed (Bean Thinking).

The respect for a higher purpose and the sensitivity toward higher values such as sustainability can be considered as a form of spiritual knowledge (Bennet and Bennet, 2008; Bratianu, 2015) defined as an individual's understanding of the meaning of the existence, finding a purpose in life and living according to deeply held personal values. For bloggers, authentic sustainability reflects their need for self-actualization achievable only through acculturation toward coffee appreciation (Bratianu, 2015). Bloggers possessing spiritual knowledge embrace ethical values which go beyond their own interests: "There is still so much more to learn, so many new things to experience, it is a journey l'm very happy to have embarked upon."

Accordingly, their actions and thoughts are guided by the emotional part of human nature and addressed to solve higher problems of meaning and value-focused on moral aspects (Bratianu, 2015). Based on the above analysis, Table 6 summarizes the main types of tacit knowledge identified from the aggregate dimensions' analysis.

\section{Discussion}

\subsection{Types of customer experiential knowledge}

The findings have empirically shown that bloggers' narratives emphasize the different dimensions of a consumption experience and do account as a source of different types of tacit knowledge as identified by the literature. In turn, the types of tacit knowledge associated with specific experiential dimensions emerging from the analysis can be considered as types of CEK, arriving at a more comprehensive understanding of the construct. Therefore, this part discusses these associations and corresponding types of CEK which have been single out through iterations between the theories and empirical analysis (Lindgreen et al., 2020).

The analysis of the first theme "actions-oriented practices and sustainable behaviors" shows that coffee consumption experiences, meant as practical and habitual ways of doing things (Roederer, 2012), are connected with conscious and rational mental processes (Gentile et al., 2007) through which bloggers solve practical needs and problems (praxeological, pragmatic and cognitive dimensions). The previous analysis also shows that these kinds of actions represent a form of intuitive (Bennet and Bennet, 2008) or practical 
Table 6 Types of CEK with their associated experiential dimensions, types of tacit knowledge and aggregate dimensions

\begin{tabular}{|c|c|c|c|c|}
\hline Aggregate dimensions & $\begin{array}{l}\text { Types of experiential } \\
\text { dimensions }\end{array}$ & $\begin{array}{l}\text { Types of tacit } \\
\text { knowledge }\end{array}$ & Illustrative quotes & Type of CEK \\
\hline \multirow[t]{2}{*}{$\begin{array}{l}\text { Actions-oriented } \\
\text { practices and } \\
\text { sustainable behaviors }\end{array}$} & $\begin{array}{l}\text { Praxeological } \\
\text { (Roederer, 2012) } \\
\text { Pragmatic and } \\
\text { cognitive (Gentile et al., } \\
\text { 2007) } \\
\text { Creative (Schmitt, 1999) }\end{array}$ & $\begin{array}{l}\text { Intuitive (Bennet and } \\
\text { Bennet, 2008) } \\
\text { Practical (Rix and } \\
\text { Lièvre, 2008) } \\
\text { Sagacious (Castillo, } \\
\text { 2002) }\end{array}$ & $\begin{array}{l}\text { "Leaving a sticky note to } \\
\text { remember the cup" (The Little } \\
\text { Black Coffee Cup) } \\
\text { "I came up with a way to reuse } \\
\text { the K-cup far more than } 10 \\
\text { times" (Roasty Coffee) }\end{array}$ & Instinctive \\
\hline & $\begin{array}{l}\text { Social (Schmitt et al., } \\
\text { 2015) } \\
\text { Lifestyle (Gentile et al., } \\
\text { 2007) } \\
\text { Praxeological } \\
\text { (Roederer, 2012) }\end{array}$ & $\begin{array}{l}\text { Collective (Collins, } \\
\text { 2010) } \\
\text { Socio-cultural (Castillo, } \\
\text { 2002) }\end{array}$ & $\begin{array}{l}\text { "With a mug like this, l'd gladly } \\
\text { deal with the "inconvenience" of } \\
\text { carrying it and washing it, just to } \\
\text { be seen with it" (Brian's Coffee } \\
\text { Spot) }\end{array}$ & Normative \\
\hline $\begin{array}{l}\text { Ritualized consumption } \\
\text { and sustainability }\end{array}$ & $\begin{array}{l}\text { Rhetorical and } \\
\text { praxeological } \\
\text { (Roederer, 2012). }\end{array}$ & $\begin{array}{l}\text { Semantic/encoded } \\
\text { Castillo, 2002; Blackler, } \\
\text { 1996) } \\
\text { Collective/socio-cultural } \\
\text { (Collins, 2010; Castillo, } \\
\text { 2002) }\end{array}$ & $\begin{array}{l}\text { "For me, coffee is less about the } \\
\text { taste and almost all about the } \\
\text { ritual. I enjoy the tranquility that } \\
\text { comes to me for the few } \\
\text { minutes" (Coffee Nate) }\end{array}$ & Symbolic \\
\hline $\begin{array}{l}\text { Sensorial skills and } \\
\text { pleasure for the } \\
\text { evaluation of } \\
\text { consumption } \\
\text { experiences }\end{array}$ & $\begin{array}{l}\text { Sensory, physical and } \\
\text { bodily (Schmitt et al., } \\
\text { 2015) } \\
\text { Sensorial (Gentile et al., } \\
\text { 2007) } \\
\text { Hedonic/sensory } \\
\text { (Roederer, 2012) }\end{array}$ & $\begin{array}{l}\text { Embodied (Bennet and } \\
\text { Bennet, 2008; Blackler, } \\
\text { 1996) } \\
\text { Somatic (Collins, 2010) }\end{array}$ & $\begin{array}{l}\text { "Coffee taste better when } \\
\text { served in a nice cup" and "even } \\
\text { if it's a disposable cup, it has to } \\
\text { be pretty and functional" } \\
\text { (Coffee Stylish) }\end{array}$ & Epicurean \\
\hline $\begin{array}{l}\text { Sustainability as a co- } \\
\text { opted and abused } \\
\text { value }\end{array}$ & $\begin{array}{l}\text { Rhetorical (Roederer, } \\
\text { 2012) } \\
\text { Relational and lifestyle } \\
\text { (Gentile et al., 2007) }\end{array}$ & $\begin{array}{l}\text { Semantic and socio- } \\
\text { cultural (Castillo, 2002) } \\
\text { Encoded and } \\
\text { encultured (Blackler, } \\
\text { 1996) } \\
\text { Collective (Collins, } \\
\text { 2010) }\end{array}$ & $\begin{array}{l}\text { "The cynic might say that the } \\
\text { best way to sell coffee these } \\
\text { days is to package it with rich } \\
\text { man's guilt relief" (The Shot) } \\
\text { "Some cafes seem too busy } \\
\text { saving the world than to make a } \\
\text { great-tasting espresso" (Bean } \\
\text { Poet) }\end{array}$ & Subcultural \\
\hline $\begin{array}{l}\text { Contrasting attitudes } \\
\text { toward mainstream } \\
\text { consumption practices }\end{array}$ & $\begin{array}{l}\text { Social (Schmitt et al., } \\
\text { 2015) } \\
\text { Relational and lifestyle } \\
\text { (Gentile et al., 2007) }\end{array}$ & $\begin{array}{l}\text { Collective (Collins, } \\
\text { 2010) } \\
\text { Encultured and } \\
\text { encoded (Blackler, } \\
\text { 1996) } \\
\text { Socio-cultural and } \\
\text { semantic (Castillo, } \\
\text { 2002) }\end{array}$ & $\begin{array}{l}\text { "What was once an alternate is } \\
\text { now becoming co-opted and } \\
\text { industrialized in the name of } \\
\text { product marketing by the big } \\
\text { coffee producers it originally } \\
\text { intended to counteract" (The } \\
\text { Shot) } \\
\text { "Organic coffee is great } \\
\text { because it is (obviously) grown } \\
\text { without chemicals and is usually } \\
\text { grown in such a way that } \\
\text { protects sensitive ecosystems" } \\
\text { (I Need Coffee) }\end{array}$ & Subcultural \\
\hline $\begin{array}{l}\text { Coffee appreciation } \\
\text { and sustainability as } \\
\text { journeys toward self- } \\
\text { actualization }\end{array}$ & $\begin{array}{l}\text { Feelings and affective } \\
\text { (Schmitt, 1999; Schmitt } \\
\text { et al., 2015) } \\
\text { Emotional (Gentile } \\
\text { et al., 2007) }\end{array}$ & $\begin{array}{l}\text { Affective and spiritual } \\
\text { (Bennet and Bennet, } \\
\text { 2008) } \\
\text { Emotional and spiritual } \\
\text { (Bratianu, 2015) }\end{array}$ & $\begin{array}{l}\text { For-here consumption is "an } \\
\text { invitation to be more careful, } \\
\text { thoughtful and conscious and } \\
\text { not to hurry" (Brian's Coffee } \\
\text { Spot) }\end{array}$ & Transcendental \\
\hline
\end{tabular}


(Rix and Lièvre) tacit knowledge, as bloggers come up with ways to address such problems in sagacious ways (Castillo, 2002). Accordingly, it is possible to identify the first type of CEK associated with the above experiential dimensions and types of tacit knowledge. Specifically, it can be defined as instinctive meant as the knowledge associated with the intuitive and sagacious grasping of what is to be done in certain situations, often associated with the capacity of coming up with creative unique solutions to practical problems, which might lead to modification of an experience such as leaving a sticky note to remember the reusable cup so that the takeaway consumption experience becomes more sustainable.

The first theme also shows that consumption experiences are associated with systems of values and behaviors which represent the appropriate conduct in a given socio-cultural context and, therefore, a person's adherence to the system implies conforming to its values and behaviors (lifestyle dimension) (Gentile et al., 2007). These sets of values and behaviors also represent a form of collective (Collins, 2010) or socio-cultural (Castillo, 2002) tacit knowledge as they are deeply embedded within socio-cultural systems and, being implicitly shared and accepted, they can only be learned through socialization. Accordingly, it is possible to identify the second type of CEK associated with the above experiential dimensions and types of tacit knowledge. Specifically, it can be defined as normative meant as a set of established but uncodified norms and well-known social conventions associated with specific consumption habits and whose understanding permits to properly behave in a given context. For example, the analysis has shown that consumers are gradually showing more effort into the adoption of reusable cups for take-away consumption as, being sustainability increasingly becoming an embedded value within the socio-cultural system under analysis, their adoption is slowly turning into a social convention.

The analysis of the second theme "ritualized consumption and sustainability" shows that coffee consumption is lived by many bloggers as a rhetorical experience, almost a ritual, embedded with hidden symbolic value. Bloggers perform "the ritual of coffee consumption" because they want to satisfy higher levels of needs such as a sense of belonging and status (rhetorical dimension) (Roederer, 2012). Although rituals can still be considered a form of collective tacit knowledge, as they represent the appropriate uncodified behavior in a given consumption situation, they are also enriched with symbolic value. Therefore, as they confer higher status to those who perform them, they indeed represent a form of semantic (Castillo, 2002) or encoded tacit knowledge (Blackler, 1996). Accordingly, it is possible to identify the third type of CEK associated with the above experiential dimension and types of tacit knowledge. Specifically, it can be defined as symbolic meaning as the knowledge associated with both the positive or negative symbolic significance implicitly given to specific elements or practices of a consumption experience. For example, the ritual of for-here consumption inherently implies a greater capacity of coffee appreciation and it confers the status of coffee experts to those performing it while, by contrast, for-here coffee in a takeaway cup inherently implies the lack of coffee appreciation.

The analysis of the third theme "sensorial skills and pleasure for the evaluation of consumption experiences" shows that the pleasure/displeasure that comes with coffee consumption experiences is often described through a sensorial assessment using all the human senses (hedonic/sensory, sensorial, physical dimensions) (Roederer, 2012; Gentile et al., 2007; Schmitt et al., 2015). The sensorial descriptions of the evaluation of a consumption experience can also be considered as somatic (Castillo, 2002) or embodied (Bennet and Bennet, 2008) tacit knowledge as they represent the capacity of evaluation of an individual through their sensorial skills which, although might seem innate, it is, in fact, the result of behavioral and sensorial training. Accordingly, it is possible to identify the fourth type of CEK associated with the above experiential dimensions and types of tacit knowledge. Specifically, it can be defined as epicurean meant the learned knowledge 
associated with the procedures adopted for evaluating a consumption experience through the senses and the capacity of differentiating between a pleasurable and a less pleasurable consumption experience. For example, the displeasure associated with takeaway cups is the result of an evaluation based on visual, taste and tactile impressions.

The fourth theme, "contrasting attitudes toward mainstream consumption practices," shows that individuals within a dominating socio-cultural system embrace, with different levels of commitment, the associated set of shared values, beliefs and norms, depending on how much socialization and acculturation into the system the individual has achieved. Therefore, the impact of such values, norms and beliefs on an individual's consumption experience (lifestyle dimension) will vary based on the strength of its sense of belonging to the sociocultural system and on how important is belonging to the socio-cultural system for the individual construction of its social identity (relational dimension) (Gentile et al., 2007). Although this is still in the realm of normative experiential knowledge, interestingly, the fourth theme also reveals how, within a dominant socio-cultural system, there might be the existence of smaller groups of individuals sharing sets of values, norms and beliefs which are, in fact, in complete opposition to those of the dominant socio-cultural system. These sets of values, norms and beliefs represent a form of encultured (Blackler, 1996) or sociocultural (Castillo, 2002) tacit knowledge. However, as previously discussed, being embedded with symbolic value, they also represent a form of semantic or encoded tacit knowledge. Accordingly, it is possible to identify the fifth type of CEK associated with the same dimensions and types of knowledge of the normative type plus semantic/encultured tacit knowledge. Specifically, it can be defined as subcultural meant as the knowledge associated with the ethos and ascribed meanings of a distinctive sub-group of people in opposition to the larger socio-cultural system to which they belong, which impact their consumption practices and the pleasure associated with them. While symbolic experiential knowledge is associated with the hidden significance given to specific consumption practices, subcultural experiential knowledge relates to consumption practices or values, which are in explicit opposition to the dominant socio-cultural system of reference. For example, Fair Trade coffee consumption was considered by many as sustainable practice and, at the same time, by others, as a co-opted practice that gives the false illusion of behaving in a sustainable way.

The fifth theme, "sustainability as a co-opted and abused value," relates to the rhetorical dimension of coffee consumption experience as it identifies the implicit and symbolic meaning some bloggers give to the concept of sustainability (Roederer, 2012). In particular, the analysis shows that, for some bloggers, sensorial pleasure and preferences are more important than sustainability since, as previously discussed, questioning the pleasure of sustainable practices often signifies the possession of coffee appreciation competencies. Accordingly, the theme can be described as subcultural experiential knowledge which has been previously defined. For example, several bloggers seemed to criticize cafes showing off too much sustainability as they felt it would reduce their sensorial pleasure during the ritual of for-here coffee consumption.

Finally, the analysis of the sixth theme, "coffee appreciation and sustainability as journeys toward self-actualization," shows how, for some individuals, coffee consumption is lived as an emotionally intense and meaningful experience arousing positive feelings such as calmness, peacefulness and consciousness (emotional dimension) (Gentile et al., 2007). Experiencing coffee consumption as emotionally intense implies, in fact, greater coffee appreciation, as well as the acknowledgment of having embarked into an acculturation process leading toward more authentic and sustainable consumption. In this way, consumption assumes a higher and more ethical purpose through which individuals can satisfy their need for self-actualization. As previously discussed, this can be considered as a form of spiritual knowledge (Bennet and Bennet, 2008; Bratianu, 2015). Accordingly, it is possible to identify the sixth type of CEK associated with the above experiential dimension 
and types of tacit knowledge. Specifically, it can be defined as transcendenta/meant as the knowledge associated with an individual highest aspirations and ideals leading toward experiences embedded with compassion, wisdom, mindfulness and appreciation of moral values and authenticity. For example, ritualized experiences such as for-here consumption, imply both greater capacity of coffee appreciation and a greater sensitiveness toward sustainability, as well as a search for more authentic consumption experiences as they are perceived as more fulfilling at a spiritual level. Table 6 summarizes the main types of experiential dimensions and tacit knowledge associated with each aggregate dimension and the corresponding type of CEK.

\subsection{Defining customer experiential knowledge}

Overall, the six distinctive types of CEK, identified through the analysis, reflect the experiential elements which contribute to define the multidimensionality of customer experience and confirm their tacit nature. Interestingly, the six types of CEK can be categorized into two distinct groups: socio-cultural contextual types and internal subjective types. The first group relates to experiential knowledge which comes from the impact of external factors on a consumption experience. As the previous analysis has shown, subcultural, normative and symbolic experiential knowledge are, respectively, influenced by ethos, established norms and symbols which are all external elements beyond an individual's control. For example, as seen in the case of for-here consumption associated with the status as a coffee expert, subcultural experiential knowledge relates to the shared meaning ascribed by a group of people to a practice or a belief which stands in opposition to the dominant socio-cultural system. By contrast, the second group relates to types of experiential knowledge, which are influenced by an individual's subjective factors. Transcendental, epicurean and instinctive experiential knowledge are, respectively, influenced by the internal elements: emotions, senses and instincts or ingenuity. Internal factors impact how a consumption experience is lived at an individual level. For example, instinctive knowledge will vary based on an individual's creativity and ingenuity as seen in the case of the different solutions provided by bloggers to overcome the difficulties encountered in the adoption of reusable cups leading to different consumption experiences. Epicurean knowledge will depend on an individual's sensorial assessment which also depends on how much sensorial training the individual has accomplished. Figure 2 shows a visual representation of the CEK framework.

Flowing from the previous conceptualizations of six different types of CEK, the paper now proposes a definition of CEK which, following an inductive/deductive integrated approach, is based on:

\section{Figure 2 Visual representation of CEK}

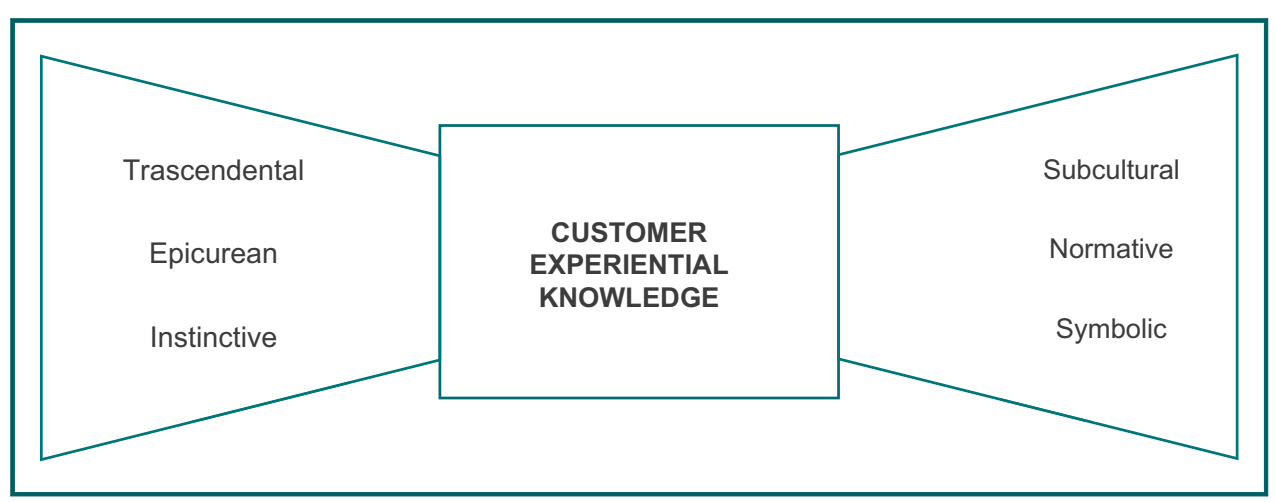


- empirical evidence coming from a structured analysis of consumers (bloggers) narratives; and

- the integration of the literature on customer experience and CKM.

Specifically, CEK is defined as follows: The knowledge tacitly possessed by customers in relation to how they live their consumption experiences according to a body of heterogeneous socio-cultural contextual factors (ethos, norms, symbols) and subjective influences (emotions, ingenuity, instincts, senses) deeply embedded into the narrative of a consumption experience.

Although the empirical analysis has confirmed the argument made by previous literature on the difficulties of acquiring tacit knowledge as it is deeply embedded within an individual personal experience, through an in-depth interpretative netnographic analysis of specialty coffee bloggers' consumption narratives, it has been possible to univocally associate experiential dimensions with specific types of tacit knowledge. Furthermore, as the analysis has also shown how, in some cases, several types of tacit knowledge are intertwined together and blurrily incorporated into one or more experiential dimensions, the proposed framework might facilitate the identification of types of tacit knowledge, which have been historically hard to extract and formalize, through the identification of the associated experiential dimension.

\section{Conclusions}

\subsection{Theoretical implications}

Research on CEK is still in its infancy and because of the tacit nature, its acquisition has often been considered a challenging task. Despite some minor and incidentals studies (Jaziri, 2019; del Vecchio et al., 2020; Bratianu et al., 2020), CEK has not been adequately addressed in the existing research and this paper represents a first attempt in providing a comprehensive CEK conceptualization which is based on sound empirical evidence.

Therefore, the paper contributes to knowledge management studies through the provision of an empirically based conceptualization of CEK which will be of use to both academics and practitioners for systematic identification and analysis of the different manifestation of CEK. Considering that consumption experiences have become a key antecedent of a firm's competitive advantage, the presented framework becomes essential for knowledge management studies.

Following a grounded theory approach (Strauss and Corbin, 1998) which combines a qualitative field study with existing literature, the paper has developed a theoretical framework, corroborated by adequate empirical evidence, which integrates different bodies of knowledge and extends previous theories (Yadav, 2010). Taking into account the challenges in identifying sources from which customer tacit knowledge can easily be gathered, such evidence was rather overdue.

The main contribution of the paper in knowledge management studies is the conceptualization of CEK as a form of tacit knowledge, which reflects the multidimensionality of $\mathrm{CX}$ and it unintentionally manifests during the narration of consumption experiences. By logically combining different types of CEK into one coherent and explanatory concept (Cornelissen, 2017), this paper provides a more precise, comprehensive and nuanced understanding of the phenomena and, by delineating its different variants, might help to recognize the different types of CEK (Maclnnis, 2011). Although web 2.0 represents, without doubt, an outlet where customer tacit knowledge might become unconsciously externalized by individuals (Carù and Cova, 2008), it is equally important to have a conceptual framework through which it can be systematically identified. 
Furthermore, while more established customer knowledge categorizations such as Gebert et al. (2003) knowledge from, for and about, represent, with no doubt, the foundational pillars of CKM, they fall short in modeling knowledge associated with more experiential types of consumption. Considering that consumption is becoming more and more experiential and subjective (Hirschman and Holbrook, 1982), structured approaches for the management of more tacit and in-depth customer insights are becoming essential for knowledge management studies.

In relation to customer experience literature, the paper confirms its multidimensional and subjective nature (Holbrook and Hirschman, 1982), as well as its more implicit emotional, symbolic and sensorial elements (Verhoef et al., 2009). Furthermore, as the paper integrates CX dimensions with tacit knowledge typologies, it enriches the multidimensionality of the concept, as, by identifying different types of CEK, speculations of new associated experiential dimensions can be made. Specifically, comparing the paper's findings with Table 1, the study has identified two additional types of experiential dimensions. Specifically, transcendental knowledge has been associated with the emotional dimension of Gentile et al. (2007), while in fact, it relates to consumption experiences which, not only are highly emotional but also have a spiritual and moral value and are often driven by self-actualization motives. Similarly, subcultural knowledge has been associated to Roederer's (2012) rhetorical (2012) and Gentile's et al. (2007) lifestyle and relational dimensions. Therefore, a subcultural experiential dimension, which incorporates both might be hypothesized.

Finally, in relation to customer insights acquisition, the paper further corroborates the value of qualitative approaches such as netnography, for the acquisition of customer tacit knowledge, as well as the value of unstructured unsolicited data as sources of more personal, deep and hidden consumer insights. Consistently with del Vecchio et al. (2020) and Holmlund et al. (2020) findings, this paper confirms the value of netnography as a complementary methodological approach to big data analysis.

\subsection{Managerial implications}

In terms of managerial value, we have demonstrated that bloggers because of their intrinsic nature, might represent for firms a relatively easy and cost-effective approach to overcome the challenging process of identifying and acquiring different types of experiential knowledge. Accordingly, once a number of suitable blogs have been identified, firms will be able to systematically obtain experiential data from their narratives according to the different experiential dimensions. Firms should consider bloggers as valuable external sources of tacit knowledge which, through an appropriate netnographic interpretation, might complement big data insights, providing a holistic vision, which merges knowledge from and about customers with the deeper and emphatic side of customer experiences by integrating emotional, sensorial and symbolic aspects.

In combination, as consumers have also started demanding greater sustainability practices (Guimarães et al., 2019), businesses feel impelled to provide offerings, which are more sustainable and, accordingly, acquire adequate customer knowledge in terms of what consumers value as sustainable consumption and how sustainable practices are incorporated into their consumption experiences.

In terms of recommendations for firms wanting to implement a more sustainable business approach, the findings provide insights on what is valued as sustainable consumption and how sustainable practices are incorporated into consumers' everyday lives. For example, firms should be aware of the disruption caused by sustainability to customers' current practices and to what extent they would be prepared to modify them for the adoption of more sustainable conduct. In general, it can be argued that commitment toward sustainability is higher when its coherence with the cultural values associated with the type of consumption is stronger. 
Firms should also be aware of over-using sustainability claims in their promotional and positioning strategies as highly invested consumers might perceive it as a loss of authenticity.

\subsection{Limitations and further development}

Being one of the first attempts of developing a conceptual framework for CEK, the paper presents several limitations which might prompt future research developments. First of all, the study could be replicated in different consumption contexts and incorporate into the analysis a richer body of data including photos and videos extracted from other social media platforms such as Instagram or YouTube. The application of the framework in other industries could also reinforce its applicability. Furthermore, the framework's applicability could also be tested in the broader organizational knowledge management context, for example, in relation to workers' and employees' working experiences. Are the same types of CEK found with employees? Can the framework be used to improve job satisfaction?

Furthermore, this study is intentionally focused on the knowledge identification and acquisition phases of the CKM process, including knowledge conversion from tacit to explicit. Therefore, future developments might focus on the knowledge creation and utilization phases. For example, quantitative approaches could be adopted to identify how each CEK dimension impacts value creation and innovation capabilities. Alternately, specific empirical cases could be used to investigate how the newly generated knowledge can serve different strategic aspects such as products or services offered, customer service, communication strategies.

\section{Note}

1 NCapture was used for data extraction of posts including these words: sustainability, sustainable, recyclable, reusable, compostable, disposable, eco, fair trade, organic, shade-grown, environment, environmental footprint.

\section{References}

Addis, M. and Holbrook, M.B. (2001), "On the conceptual link between mass customization and experiential consumption: an explosion of subjectivity", Journal of Consumer Behaviour, Vol. 1 No. 1, pp. 50-66.

Arsel, Z. and Bean, J. (2013), "Taste regimes and market-mediated practice", Journal of Consumer Research, Vol. 39 No. 5, pp. 899-917.

Becker, L. and Jaakkola, E. (2020), "Customer experience: fundamental premises and implications for research", Journal of the Academy of Marketing Science, Vol. 48 No. 4, pp. 630-648.

Belk, R.W., Sherry, J.F. and Wallendorf, M. (1988), "A naturalistic inquiry into buyer and seller behavior at a swap meet", Journal of Consumer Research, Vol. 14 No. 4, pp. 449-470.

Bennet, D. and Bennet, A. (2008), "Engaging tacit knowledge in support of organizational learning", VINE, Vol. 38 No. 1, pp. 72-94.

Blackler, F. (1996), "Knowledge, knowledge work and organizations: an overview and interpretation", Organization Studies, Vol. 16 No. 6, pp. 1021-1046.

Bourdieu, P. (1984), Distinction: A Social Critique of the Judgement of Taste, Harvard University Press, Cambridge.

Bratianu, C. (2015), "Organizational knowledge dynamics: managing knowledge creation", Acquisition, Sharing, and Transformation, IGI Global.

Bratianu, C., Vătămănescu, E.M., Anagnoste, S. and Dominici, G. (2020), "Untangling knowledge fields and knowledge dynamics within the decision-making process", Management Decision, Vol. 59 No. 2, pp. 306-323. 
Bretschneider, U. and Zogaj, S. (2016), "Exploring strategies for capturing customer's tacit knowledgein customer integration methods", International Journal of Knowledge Management, Vol. 12 No. 2, pp. 1-19.

Busacca, B., Cillo, P. and Mazursky, D. (2008), "From market research to creativity templates: leveraging tacit knowledge for ideation", in Tollin, K. and Carù, A. (Eds), Strategic Market Creation, John Wiley and Sons, Chichester, pp. 3-26.

Carù, A. and Cova, B. (2007), "Consuming experience: an introduction", in Carù, A. and Cova, B. (Eds), Consuming Experience, Routledge, pp. 3-16.

Carù, A. and Cova, B. (2008), "Small versus big stories in framing consumption experiences", Qualitative Market Research: An International Journal, Vol. 11 No. 2, pp. 166-176.

Castillo, J. (2002), "A note on the concept of tacit knowledge", Journal of Management Inquiry, Vol. 11 No. 1, pp. 46-57.

Chaney, D., Lunardo, R. and Mencarelli, R. (2018), "Consumption experience: past, present and future", Qualitative Market Research: An International Journal, Vol. 21 No. 4, pp. 402-420.

Cayla, J. and Arnould, E. (2014), "Ethnographic stories for market learning", Journal of Marketing, Vol. 77 No. 4, pp. 1-16.

Chierici, R., Mazzucchelli, A., Garcia-Perez, A. and Vrontis, D. (2019), "Transforming big data into knowledge: the role of knowledge management practice", Management Decision, Vol. 57 No. 8 , pp. 1902-1922.

Chua, A.Y.K. and Banerjee, S. (2013), "Customer knowledge management via social media: the case of Starbucks", Journal of Knowledge Management, Vol. 17 No. 2, pp. 237-249.

Collins, H. (2010), Tacit and Explicit Knowledge, University of Chicago Press, Chicago IL.

Cook, S.N. and Brown, J.S. (1999), "Bridging epistemologies: the generative gap between organizational knowledge and organizational knowing", Organizational Science, Vol. 10 No. 4, pp. 382-400.

Cornelissen, J. (2017), "Editor's comments: developing propositions, a process model, or a typology? Addressing the challenges of writing theory without a boilerplate", Academy of Management Review, Vol. 42 No. 1, pp. 1-9.

Del Giudice, M., Della Peruta, M.R. and Maggioni, V. (2015), "A model for the diffusion of knowledge sharing technologies inside private transport companies", Journal of Knowledge Management, Vol. 19 No. 3, pp. 611-625

Del Vecchio, P., Mele, G., Passiante, G., Vrontis, D. and Fanuli, C. (2020), "Detecting customers knowledge from social media big data: toward an integrated methodological framework based on netnography and business analytics", Journal of Knowledge Management, Vol. 24 No. 4, pp. 799-821.

Dinur, A. (2011), "Tacit knowledge taxonomy and transfer: case-based research", Journal of Behavioral and Applied Management, Vol. 12 No. 3, pp. 246-281.

Eiseman, D. and Jonsson, M. (2019), "Leveraging the coffee experience as a tool for engagement with climate change", Qualitative Market Research: An International Journal, Vol. 22 No. 4, pp. 570-581.

Elliott, R. and Jankel-Elliot, N. (2003), "Using ethnography in strategic consumer research", Qualitative Market Research: An International Journal, Vol. 6 No. 4, pp. 215-223.

Fiano, F., Mueller, J., Paoloni, N., Farina Briamonte, M. and Magni, D. (2020), "Evaluating fashion retailers' intellectual capital: key money as a part of customer capital”, Journal of Intellectual Capital.

Gebert, H., Geib, M., Kolbe, L.M. and Brenner, W. (2003), "Knowledge-enabled customer relationship management", Journal of Knowledge Management, Vol. 7 No. 5, pp. 107-123.

Geertz, C. (1973), The Interpretation of Cultures, Basic Books, New York, NY.

Gentile, C., Spille, N. and Noci, G. (2007), "How to sustain the customer experience: an overview of experience components that co-create value with the customer", European Management Journal, Vol. 25 No. 5, pp. 395-410.

Gherardi, S. (2016), "To start practice theorizing a new: the contribution of the concepts of agencement and formativeness", Organization, Vol. 23 No. 5, pp. 680-698.

Gioia, D.A., Corley, K.G. and Hamilton, A.L. (2013), "Seeking qualitative rigor in inductive research: notes on the Gioia methodology", Organizational Research Methods, Vol. 16 No. 1, pp. 15-31. 
Guimarães, E.R., Leme, P.H.M.V., De Rezende, D.C., Pereira, S.P. and Dos Santos, A.C. (2019), "The brand new Brazilian specialty coffee market”, Journal of Food Products Marketing, Vol. 25 No. 1, pp. 49-71.

He, W., Feng-Kwei, W. and Vasudeva, A. (2017), "Managing extracted knowledge from big social media data for business decision making", Journal of Knowledge Management, Vol. 21 No. 2, pp. 275-294.

Hebdige, D. (1979), Subculture: The Meaning of Style, Methuen, London.

Helkkula, A., Kelleher, C. and Pihlstrom, M. (2012), "Characterizing value as an experience: implications for service researchers and managers", Journal of Service Research, Vol. 15 No. 1, pp. 59-75.

Hirschman, E. and Holbrook, M. (1982), "Hedonic consumption: emerging concepts, methods and propositions", Journal of Marketing, Vol. 46 No. 3, pp. 92-101.

Hofacker, C.F. and Malthouse, E.C. (2016), "Big data and consumer behavior: imminent opportunities", Journal of Consumer Marketing, Vol. 33 No. 2, pp. 89-97.

Holbrook, M.B. and Hirschman, E.C. (1982), "The experiential aspects of consumption: consumer fantasies, feelings, and fun”, Journal of Consumer Research, Vol. 9 No. 2, pp. 132-140.

Hollebeek, L.D., Juric, B. and Tang, W. (2017), "Virtual brand community engagement practices: a refined typology and model", Journal of Services Marketing, Vol. 31 No. 3, pp. 204-217.

Holmlund, M., Van Vaerenbergh, Y., Ciuchita, R., Ravald, A., Sarantopoulos, P., Villaroel Ordenes, F. and Zaki, M. (2020), "Customer experience management in the age of big data analytics: a strategic framework", Journal of Business Research, Vol. 116, pp. 356-365.

Holt, B.D. (1995), "How consumers consume: a typology of consumption practices", Journal of Consumer Research, Vol. 22 No. 1, pp. 1-16.

Homburg, C., Jozić, D. and Kuehnl, C. (2017), "Customer experience management: toward implementing an evolving marketing concept", Journal of the Academy of Marketing Science, Vol. 45 No. 3, pp. 377-401.

Hsu, H.Y. and Tsou, H.T. (2011), "Understanding customer experiences in online blog environments", International Journal of Information Management, Vol. 31 No. 6, pp. 510-523.

Kane, H., Ragsdell, G. and Oppenheim, C. (2006), "Knowledge management methodologies", Electronic Journal of Knowledge Management, Vol. 4 No. 2, pp. 141-152.

Kozinets, R. (2002), "The field behind the screen: using ethnography for marketing research in online communities", Journal of Marketing Research, Vol. 39 No. 1, pp. 61-72.

Kozinets, R. (2020), Netnography, Sage, Los Angeles.

Izogo, E.E. and Jayawardhena, C. (2018), "Online shopping experience in an emerging e-retailing market: towards a conceptual model”, Journal of Consumer Behaviour, Vol. 17 No. 4, pp. 379-392.

Jaziri, D. (2019), "The advent of customer experiential knowledge management approach (CEKM): the integration of offline and online experiential knowledge", Journal of Business Research, Vol. 94, pp. 241-256.

Jang, J.Y., Kim, W.G. and Lee, H.Y. (2015), "Coffee shop consumers' emotional attachment and loyalty to green stores: the moderating role of green consciousness", International Journal of Hospitality Management, Vol. 44, pp. 146-156.

KranzbüHler, A., Kleijnen, M.H.P., Morgan, R.E. and Teerling, M. (2018), "The multilevel nature of customer experience research: an integrative review and research agenda", International Journal of Management Reviews, Vol. 20 No. 2, pp. 433-456.

Levy, M. (2009), "Web 2.0 implications on knowledge management", Journal of Knowledge Management, Vol. 13 No. 1, pp. 120-134.

Lindgreen, A., Di Benedetto, C.A., Brodie, R.J. and van der Borgh, M. (2020), "Editorial: how to undertake great cross-disciplinary research", Industrial Marketing Management, Vol. 90, pp. A1-A5.

McCracken, G.D. (1990), Culture and Consumption: New Approaches to the Symbolic Character of Consumer Goods and Activities (Vol. 1), IN University Press, Bloomington.

MacInnis, D.J. (2011), "A framework for conceptual contributions in marketing", Journal of Marketing, Vol. 75 No. 4, pp. 136-154.

Maciel, A.F. and Wallendorf, M. (2017), "Taste engineering: an extended consumer model of cultural competence constitution", Journal of Consumer Research, Vol. 43 No. 5, pp. 726-746. 
Massa, C. and Bédé, S. (2018), "A consumer value approach to a holistic understanding of the winery experience”, Qualitative Market Research: An International Journal, Vol. 21 No. 4, pp. 530-548.

Nonaka, I. (1994), "A dynamic theory of organizational knowledge creation", Organization Science, Vol. 5 No. 1, pp. 14-37.

Nonaka, I. and Takeuchi, H. (1995), The Knowledge Creating Company, Oxford University Press, New York, NY.

Pascucci, F. (2018), "The export competitiveness of Italian coffee roasting industry", British Food Journal, Vol. 120 No. 7 , pp. 1529-1546.

Pine, I.I.B.J. and Gilmore, J.H. (1998), "Welcome to the experience economy", Harvard Business Review, pp. 97-106.

Polanyi, M. (1966), The Tacit Dimension, Routledge and Kegan Paul, London.

Quintao, R.T., Brito, E. and Belk, R.W. (2017), "Connoisseurship consumption community and its dynamics", Review of Business Management, Vol. 19 No. 63, pp. 1-17.

Rageh, A., Melewar, T.C. and Woodside, A.G. (2013), "Using netnography research method to reveal the underlying dimensions of the customer/tourist experience", Qualitative Market Research: An International Journal, Vol. 16 No. 2, pp. 126-149.

Ransbotham, S., Kiron, D. and Prentice, P.K. (2015), "Minding the analytics gap", MIT Sloan Management Review, Vol. 56 No. 3, pp. 63-68.

Reid, E. and Duffy, K. (2018), "A netnographic sensibility: developing the netnographic/social listening boundaries”, Journal of Marketing Management, Vol. 34 Nos 3/4, pp. 263-286.

Rix, G. and Lièvre, P. (2008), "Towards a codification of practical knowledge", Knowledge Management Research \& Practice, Vol. 6 No. 3, pp. 225-232.

Roberts, D.L., Piller, F.T. and Lüttgens, D. (2016), "Mapping the impact of social media for innovation: the role of social media in explaining innovation performance in the PDMA comparative performance assessment study", Journal of Product Innovation Management, Vol. 33 No. S1, pp. 117-135.

Roederer, C. (2012), "A contribution to conceptualizing the consumption experience: emergence of the dimensions of an experience through life narratives", Recherche et Applications en Marketing (English Edition), Vol. 27 No. 3, pp. 81-95.

Rook, D.W. (1985), "The ritual dimension of consumer behaviour", Journal of Consumer Research, Vol. 12 No. 3, pp. 251-264.

Rowley, J. (2002), "Eight questions for customer knowledge management in e-business", Journal of Knowledge Management, Vol. 6 No. 5, pp. 500-511.

Said, E., Macdonald, E.K., Wilson, H.N. and Marcos, J. (2015), "How organisations generate and use customer insight", Journal of Marketing Management, Vol. 31 Nos 9/10, pp. 1158-1179.

Scaraboto, D. and Fischer, E. (2013), "Frustrated fatshionistas: an institutional theory perspective on consumer quests for greater choice in mainstream markets", Journal of Consumer Research, Vol. 39 No. 6, pp. 1234-1257

Schau, H.J., Muñiz, A.M., Jr and Arnould, E.J. (2009), "How Brand community practices create value", Journal of Marketing, Vol. 73 No. 5, pp. 30-51.

Schmitt, B. (1999), "Experiential marketing”, Journal of Marketing Management, Vol. 15 Nos 1/3, pp. 53-67.

Schmitt, B.H. (2003), "The customer experience management: a revolutionary approach to connecting with your customers", available at: www.books.google.com/books/customer_Experience_management

Schmitt, B., Brakus, J. and Zarantonello, L. (2015), "From experiential psychology to consumer experience", Journal of Consumer Psychology, Vol. 25 No. 1, pp. 166-171.

Strauss, A. and Corbin, J. (1998), Basics of Qualitative Research, 2nd ed., Sage, Thousand Oaks, CA.

Svenson, F. (2018), "Smartphone crises and adjustments in a virtual P3 community - doing sustainability oriented smartphone consumption", Journal of Marketing Management, Vol. 34 Nos 7/8, pp. 664-693.

Taghizadeh, S., Abidur Rahman, M.D. and Mosharref, H. (2018), "Knowledge from customer, for customer or about customer: which triggers innovation capability the most?", Journal of Knowledge Management, Vol. 22 No. 1, pp. 62-182. 
Taylor, S.J. and Bogdan, R. (1984), Introduction to Qualitative Research Methods, Wiley, New York, NY.

Terry, G., Hayfield, N., Clarke, V. and Braun, V. (2017), "Thematic analysis", in Stainton, W.R. and Willig, C. (Eds), The SAGE Handbook of Qualitative Research in Psychology, 2nd ed., Sage, London.

Thornton, S. (1996), Club Cultures: Music, Media, and Subcultural Capital, Wesleyan University Press, Middletown.

Thusy, A. and Morris, L. (2004), "From CRM to customer experience: a new realm for innovation", Business Digest, January, pp. 1-8.

Usai, A., Pironti, M., Mital, M. and Aouina Mejri, C. (2018), "Knowledge discovery out of text data: a systematic review via text mining", Journal of Knowledge Management, Vol. 22 No. 7, pp. 1471-1488.

Verhoef, P.C., Reinartz, W.J. and Krafft, M. (2009), "Customer engagement as a new perspective in customer management", Journal of Service Research, Vol. 13 No. 3, pp. 247-252.

Wagner, D., Vollmar, G. and Wagner, H.T. (2014), "The impact of information technology on knowledge creation: an affordance approach to social media", Journal of Enterprise Information Management, Vol. 27 No. 1, pp. 31-44.

Wilhelm, S., Gueldenberg, S. and Güttel, W. (2013), "Do you know your valuable customers?", Journal of Knowledge Management, Vol. 17 No. 5, pp. 661-676.

Yadav, M. (2010), "The decline of conceptual articles and implications for knowledge development", Journal of Marketing, Vol. 74 No. 1, pp. 1-19.

Zhang, Z. (2011), "Customer knowledge management and the strategies of social software", Business Process Management Journal, Vol. 17 No. 1, pp. 82-106.

\section{Further reading}

Chen, Y.H. and Su, C.T. (2006), "A Kano-CKM model for customer knowledge discovery", Total Quality Management \& Business Excellence, Vol. 17 No. 5, pp. 589-560.

Davenport, T., Harris, J.G. and Kohl, A. (2001), "How do they know their customers so well?", MIT Sloan Management Review, Vol. 42 No. 2, pp. 63-73.

Mahr, D. and Annouk, L. (2012), "Virtual lead user communities: drivers of knowledge creation for innovation", Research Policy, Vol. 41 No. 1, pp. 167-177.

Moraes, C., Carrigan, M. and Szmigin, I. (2012), "The coherence of inconsistencies: attitude-behaviour gaps and new consumption communities", Journal of Marketing Management, Vol. 28 Nos 1/2, pp. 103-128.

Nonaka, I. and Konno, N. (1998), "The concept of 'Ba': building a foundation for knowledge creation”, California Management Review, Vol. 40 No. 3, pp. 40-54.

Ravi, K. and Ravi, V. (2015), "A survey on opinion mining and sentiment analysis: tasks, approaches and applications", Knowledge-Based Systems, Vol. 89, pp. 14-46.

Salomann, H., Dous, M., Kolbe, L. and Brenner, W. (2005), "Rejuvenating customer management: how to make knowledge for, from and about customers work", Journal of European Management, Vol. 23 No. 4, pp. 392-403.

Thompson, C.J. (2019), "The 'big data' myth and the pitfalls of 'thick data' opportunism: on the need for a different ontology of markets and consumption", Journal of Marketing Management, Vol. 35 Nos 3/4, pp. 207-230.

Trevinal, A.M. and Stenger, T. (2014), "Toward a conceptualization of the online shopping experience", Journal of Retailing and Consumer Services, Vol. 21 No. 3, pp. 314-326.

\section{Corresponding author}

Federica Pascucci can be contacted at: f.pascucci@univpm.it

For instructions on how to order reprints of this article, please visit our website: www.emeraldgrouppublishing.com/licensing/reprints.htm

Or contact us for further details: permissions@emeraldinsight.com 